\title{
The LOGIC of National Policies and Strategies for Open Educational Resources
}

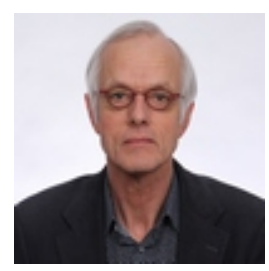

Fred Mulder

Open Universiteit in The Netherlands

\section{Abstract}

In its first decade (2001-2010) the OER movement has been carried by numerous relevant and successful projects around the globe. These were sometimes large-scale but more often not, and they were primarily initiated by innovating educational institutions and explorative individual experts. What has remained, however, is the quest for a sustainable perspective, in spite of the many attempts in the OER community for clearcut solutions to the problem of sustainability. This is a major barrier for mainstreaming the OER approach in national educational systems.

At the end of the first decade, and more so at the beginning of the second decade (20112020), we are witnessing in a few countries emerging efforts to develop and establish a national OER approach. That is required in order to break down the barrier for mainstreaming OER. Making the OER approach sustainable cannot be left to the educational institutions only, but should be facilitated in a national setting.

Keywords: Open educational resources; national policies; strategies 


\section{National Initiatives}

India was the first country to adopt OER in its Report to the Nation 2007 and with its launch of the National E-content and Curriculum Initiative (National Knowledge Commission, 2007; Vijay Kumar, 2009). The Netherlands followed in 2009 with their Wikiwijs Program which aims at mainstreaming OER in all educational sectors, from primary through university education. It has been running from 2009 until 2013 with a total budget of 8 million euros and OUNL is one of the two leading partners. In 2011 the US Departments of Labor and Education started a four-year 2 billion dollar program in which among other activities OER will be developed for community colleges and career training.

Many other countries (for example, Brazil, China, Indonesia, Japan, Korea, Poland, South Africa, Turkey, UK, Vietnam) have introduced specific measures or subsidies in order to stimulate OER. Some of these countries are considering a national OER approach.

\section{The Dutch Case: Wikiwijs}

Wikiwijs is a rather ambitious and complex program, which is at the forefront of emerging national policies and strategies. It was launched by the Dutch minister of education in December 2008 and received broad support from all political parties in Parliament by April 2009, starting in the summer of 2009, a remarkably fast process! The intended effects on society are improved quality, efficiency, and services in teaching and learning.

Wikiwijs is primarily created for and by educators (teachers and professors), although others (experts, practitioners, students, etc.) can use it and contribute as well. Therefore ownership of Wikiwijs lies in the educational field, that is, in the first place with users. The five-year budget of 8 million euros does not allow Wikiwijs to make payments for the development of content/learning materials, purchasing licenses for software, or for support facilities and tools. The development of content itself is supposed to be done in general by the publicly funded educational institutions and organizations within their regular budgets. The Wikiwijs program is carried by the following areas of activity: content, professionalism, accessibility/technology, communities, research, communication, and program management (Mulder, 2009).

From 2009 until 2011 Wikiwijs was in its initial implementation stage with intense user evaluation, many committed stakeholders, and good progress, but there were also bottlenecks and lessons learned, which informed the Program Plan for the next stage towards a sustainable perspective (Wikiwijs, 2011). This stage is to be characterized by user participation, a differentiation from the generic approach into the specific educational sectors, and the establishment of firm ownership with relevant partners in those sectors. 
In Figure 1 we show a tree of objectives derived from the operation and evaluation of Wikiwijs 2009-2011, which have supported the activities and the further development of Wikiwijs 2011-2013.

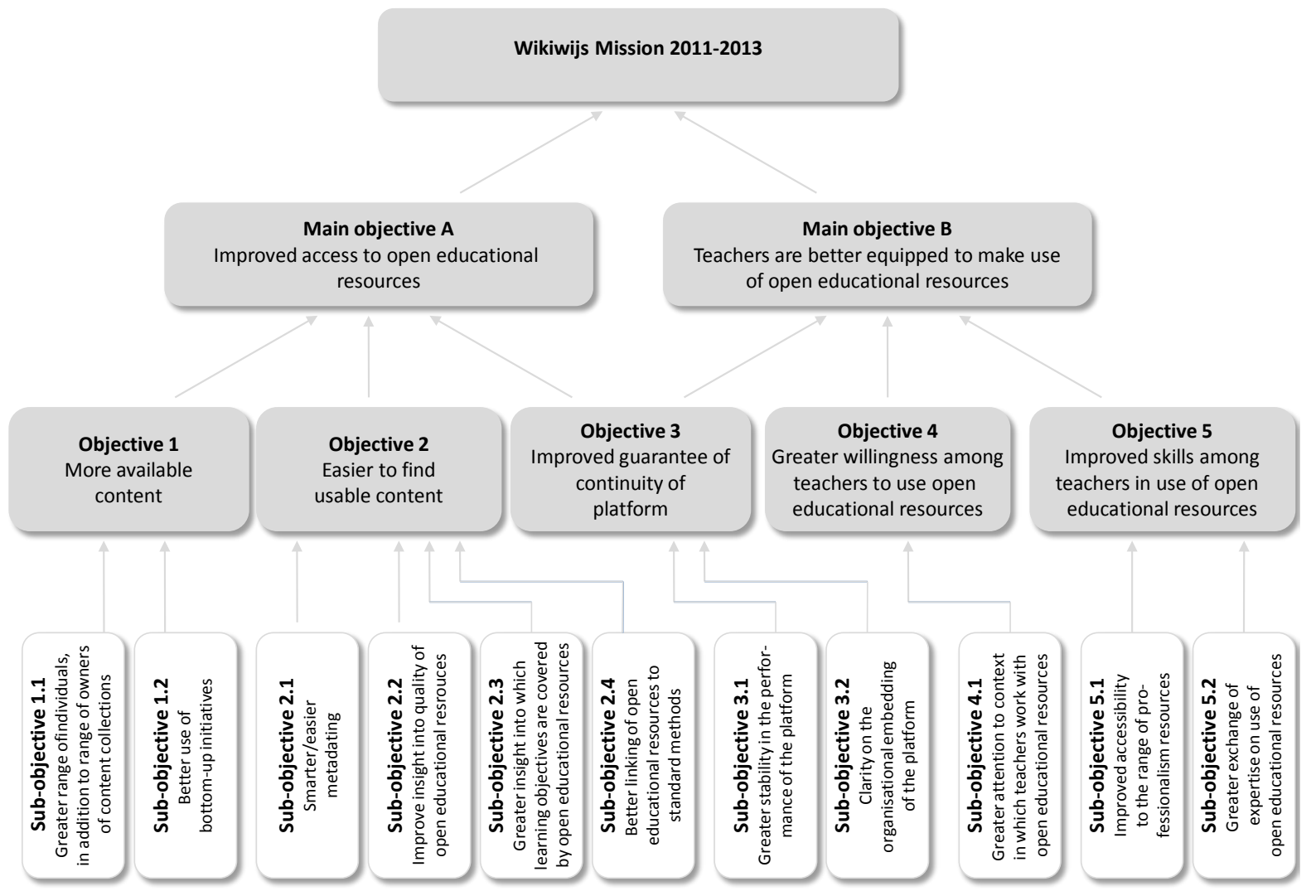

Figure 1. An objectives tree for Wikiwijs 2011-2013.

\section{National OER Strategy According to Wikiwijs}

The Program Plan 2011-2013 reaffirms its support for primary to university education and the freedom of teachers to use open (and closed) OER. It calls for the development of a central repository of OER where teachers can develop and share their creations or adapt them to work with closed resources (Wikiwijs, 2011).

\section{"Knowledge is a Public Good"}

This almost trivial sounding notion is included as one of the concluding statements in a report published by the Taskforce on OER of the ICDE (International Council for Open and Distance Education). Sustainability should not be taken for granted - it requires public funding (Mulder \& Rikers, 2008). Similar statements or implications related to the "knowledge is a public good" notion can be recorded from other sources including 
the Cape Town Open Education Declaration (2007) and the US government, which supports opening government content as a cost-efficient method of improving teaching quality (Plotkin, 2010).

\section{Government's Responsibilities}

J ohn Daniel has referred to the iron triangle, spanned by three sides: one for access, one for quality, and one for cost. It is called an iron triangle because improvement of one of these three performance indicators will inevitably deteriorate one of the two or both other performance indicators if circumstances and conditions are not changed. However, he claims that the use of technology could break down this impasse (Daniel, 2009).

In this paper we present a modification of this model, which is different in three ways.

1. The performance indicators are accessibility, quality, and efficiency. The first two correspond to the first two in the iron triangle, and for both, maximization is the target. As a third indicator we have chosen costefficiency rather than cost, giving the advantage that then for all three indicators maximization is the aim (and not - as with cost - minimization).

2. The intervention should not be the use of technology in general but more specifically the utilization of OER. This will reinforce the argument because there will be less doubt with respect to the effectiveness of any specific intervention with OER.

3. Instead of a planar (2-dimensional) triangle, a 3-dimensional representation better fits the modelling with three performance indicators.

\section{Education Performance in 3D}

Figure 2(a) shows such a 3D representation of the performance of Dutch education at a certain moment with values along the three axes for accessibility, quality, and costefficiency. These are interconnected through a three-point plane. Suppose one wants to improve the performance in efficiency. In Figure 2(b) we see an example (in red), where indeed cost-efficiency is increasing, however at the cost of both quality and accessibility, which are decreasing. Figure 2(c) presents another example where the performance in quality is better, but this goes hand-in-hand with lower cost-efficiency and more or less equal accessibility.

Figure 2 illustrates the deadlock situation (i.e., with unaltered circumstances and conditions). 

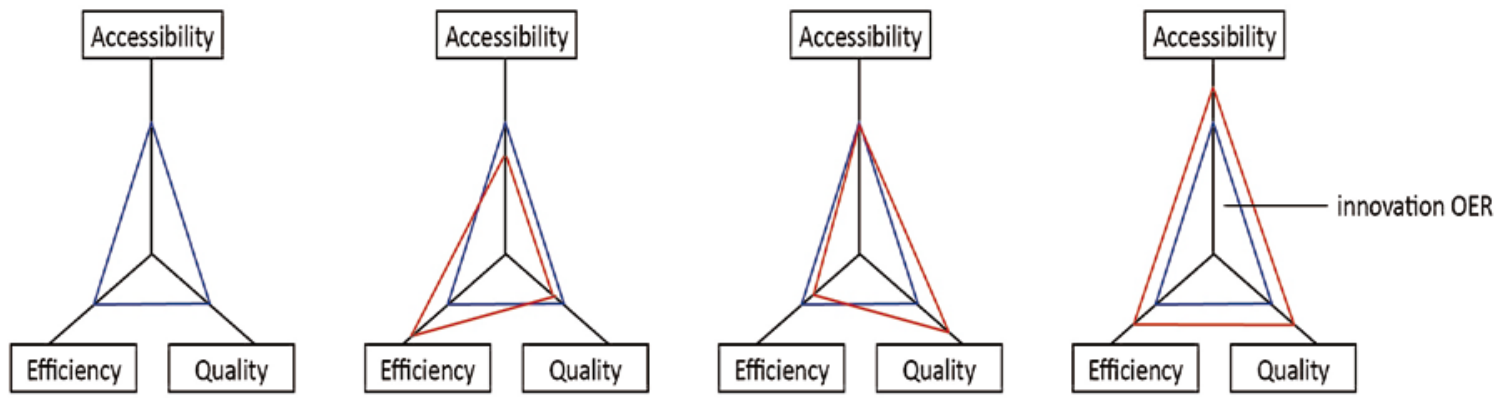

(a)

(b)

(c)

(d)

initial situation

greater efficiency

higher quality

OER situation

Figure 2. Performance of Dutch education along the three axes accessibility, quality, and efficiency.

If circumstances and conditions do change, the pattern can look different. A radical system intervention with OER (see Figure 2(d)) is an example of an innovation, which can result in simultaneous performance improvement in all three dimensions. Indeed, the accessibility of the learning materials is at a maximum with their full and free online availability. And the quality is being served with OER, because many more experts and users are involved in the development of the learning materials, which moreover are evaluated, corrected, and reviewed. Finally, cost-efficiency is promoted since there is actually no rationale any more for multiple full-scale development of courses on the same subject with similar learning objectives by different educational institutions. And one could add that OER also contributes to an extra (fourth) dimension of innovation. 


\section{Conclusions}

The title of this paper, The LOGIC of National Policies and Strategies for Open Educational Resources, can now be appreciated.

A. The more or less general institutional OER sustainability bottleneck can be overcome through national OER policies and strategies.

B. In this context, it is appropriate to refer to the three-fold responsibility of governments for education, namely to promote and ensure accessibility, quality, and efficiency.

C. The national performance in these three dimensions is deadlocked, which means that a simultaneous performance improvement in all three is not possible, at least not under unaltered circumstances and conditions.

D. This education 3D performance deadlock can be removed by a radical system intervention with OER.

E. By mainstreaming OER in all educational sectors, as intended in Wikiwijs, the government takes responsibility for the sustainability of such an OER based educational system.

F. OER represents a significant innovation in our knowledge-based society and, for example, offers the European Union (EU) a potent recipe in its 2020 modernization agenda for higher education.

A final remark should be made here, namely that mainstreaming OER through a national approach does not necessarily increase the macro budget for education. A limited reallocation, for example resulting in an OER fund, which is skimmed from the overall education budget, seems sufficient. It's as simple as that.

\section{Epilogue}

There is a growing interest in national OER policies and strategies, not only in countries but also in international organizations like UNESCO, OECD, EU, and COL (Commonwealth of Learning).

In 2011, for example, OECD decided to create a survey on OER in the OECD membership by distributing to all OECD countries a questionnaire containing a range of questions on the status of OER involvement and activity with a special focus on national policy matters. The response rate was very high (over 80\%) and the response content was certainly relevant and encouraging in that it showed a widespread interest, increasing activity, and a surprising attention to policy matters in OER (OECD, 2012).

In J une 2012 UNESCO organized the World Open Educational Resources Congress in its headquarters in Paris in full partnership with COL. This was the finale of a joint 
COL/UNESCO project called Fostering Governmental Support for Open Educational Resources Internationally. In the build-up to this congress six regional policy forums were organized, and these were preceded by a two-year COL/ UNESCO project entitled Taking OER beyond the OER Community: Policy and Capacity, which included the publication of two documents: A Basic Guide to Open Educational Resources and Guidelines for OER in Higher Education.

In the first half of 2012 UNESCO sent an OER questionnaire to all UNESCO member countries, which was similar to the OECD OER questionnaire (a few questions were not included). This is important since it is therefore possible to link the data from both questionnaires. The results were presented at the World OER Congress in J une and the UNESCO Declaration on OER was adopted at the World OER Congress. 


\section{References}

Daniel, J . (2009). Internationalisation, regionalisation and globalisation: Breaking out of the iron triangle. Speech at the 2009 UNESCO World Conference on Higher Education in Paris, France. Retrieved from http:// www.col.org/ resources/ speeches/2009presentation/ Pages/ 2009-0706.aspx

Mulder, F. (2009). The Dutch case with OER: An emerging national strategy. Keynote address at OpenEd 2009 in Vancouver, Canada. Retrieved from http:// openedconference.org/2009/archives/ 1069

Mulder, F. (2010). Open .... Address during the Rectorate handover at Open Universiteit in Heerlen, The Netherlands. Retrieved from http:// www.ou.nl/Docs/dies\%20natalis/ Redeboek\%20rectoraatsoverdracht\%2 02010_DEF.pdf

Mulder, F., \& Rikers, J . (Eds). (2008). A golden combi?! - OER and open, flexible and distance learning (Final Report ICDE Global Taskforce on OER). Oslo: ICDE. Retrieved from http:// www.icde.org/Final+Report+from+the+OER+Task+Force.9UFRzG4_.i ps

National Knowledge Commission. (2007). Report to the Nation 2007. New Delhi: Government of India. Retrieved from http://knowledgecommission.gov.in/reports/report07.asp

OECD (2012) / Hylén, J ., Van Damme, D., Mulder, F., \&D’Antoni, S. (2012). Open educational resources: Aanalysis of responses to the OECD country questionnaire (OECD Education Working Papers No. 76). Paris: OECD Publishing. Retrieved from http://dx.doi.org/ 10.1787/5k990rjhvtlv-en

Plotkin, H. (2010). Free to learn. An open educational resources policy development guidebook for community college governance officials. San Francisco: Creative Commons. Retrieved from http:// wiki.creativecommons.org/Free to Learn_Guide

Vijay Kumar, M.S. (2009). Open educational resources in India's national development. Open Learning, 24(1), 77-84. Retrieved from http:// www.informaworld.com/smpp/title $\sim$ content $=\mathrm{g} 909097565 \sim \mathrm{db}=\mathrm{all}$

Wikiwijs (2011). Wikiwijs Program Plan 2011-2013: Open educational resources via Wikiwijs in a sustainable perspective. Retrieved from http:// openserviceblog.files.wordpress.com/ 2011/ 09/ 110815-wikiwijsprogram-plan-2011-2013-def.pdf 


\section{URLs}

CapeTown-2007

http:// www.capetowndeclaration.org/read-the-declaration

CC-Plotkin

http:// wiki.creativecommons.org/Free to Learn Guide

COL-UNESCO-BasicGuide

http:// www.col.org/ resources/publications/ Pages/ detail.aspx?PID=357

COL-UNESCO-GuideLines

http:// www.col.org/ resources/publications/Pages/detail.aspx?PID=364

ICDE-OERTF-2008

http:// www.icde.org/Final+Report+from+the+OER+Task+Force.9UFRzG4_.ips

NKC-India-2007

http://knowledgecommission.gov.in/reports/report07.asp

OpenEd-2009

http:// openedconference.org/2009/archives/ 1069

OpenLearning-Special Issue

http://www.informaworld.com/smpp/title $\sim$ content=g909097565 $\sim \mathrm{db}=\mathrm{all}$

OU-rect-2010

http:// www.ou.nl/ Docs/dies\%20natalis/Redeboek\%20rectoraatsoverdracht\%202010 DEF.pdf

TAACCCT

http:// creativecommons.org/taa-grant-program

UNESCO Declaration on OER

http:// www.unesco.org/new/ fileadmin/MULTIMEDIA/HQ/CI/CI/ pdf/Events/Paris\% 200ER\%20Declaration_01.pdf 
UNESCO-WCHE-2009

http:// www.col.org/resources/speeches/2009presentation/Pages/2009-07-06.aspx

UNESCO-WOERC-2012

http://www.unesco.org/new/ fileadmin/MULTIMEDIA/HQ/CI/CI/pdf/CI_Informatio n_Meetings/2012_world_oer_congress_en.pdf

Wikiwijs

http://www.wikiwijs.nl/task/international.psml

Wikiwijs-PP-2011

http:// openserviceblog.files.wordpress.com/2011/ 09/ 110815-wikiwijs-program-plan2011-2013-def.pdf

\section{Athabasca University $\mathbf{Z}$}

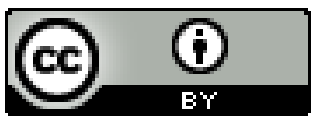

